\title{
Petrography and Geochemical Features of the Coastal Plain Sands Facies (Benin Formation) Around Nekede and Azara Egbelu Areas, Niger Delta Basin Southeast Nigeria
}

\author{
Julius Bajabu Kwache ${ }^{1, *}$, Izu Mike Akaegbobi ${ }^{2}$, Razak Gboyega Olademeji ${ }^{3}$, Justin Anumnu ${ }^{4}$ \\ ${ }^{1}$ Department of Regional Geology, Nigerian Geological Survey Agency, Adamawa State Office, Yola, Nigeria \\ ${ }^{2}$ Department of Geology, University of Ibadan, Ibadan, Nigeria \\ ${ }^{3}$ Department of Regional Geology, Nigerian Geological Survey Agency, Federal Capital Territory, Abuja, Nigeria \\ ${ }^{4}$ Department of Regional Geology, Nigerian Geological Survey Agency, Enugu, Nigeria
}

\section{Email address:}

jbkwache@gmail.com (J. B. Kwache), izumike1970@gmail.com (I. M. Akaegbobi), oladi25@yahoo.com (R. G. Olademeji) justin_aj20@yahoo.com (J. Anumnu)

\section{To cite this article:}

Julius Bajabu Kwache, Izu Mike Akaegbobi, Razak Gboyega Olademeji, Justin Anumnu. Petrography and Geochemical Features of the Coastal Plain Sands Facies (Benin Formation) Around Nekede and Azara Egbelu Areas, Niger Delta Basin Southeast Nigeria. International Journal of Mineral Processing and Extractive Metallurgy. Vol. 2, No. 6, 2017, pp. 87-91. doi: 10.11648/j.ijmpem.20170206.11

Received: June 29, 2017; Accepted: July 27, 2017; Published: November 5, 2017

\begin{abstract}
The Coastal Plain Sands Facies (Benin Formation) of the Niger Delta Basin consists of 99.8\% thick accumulation of massive, loose, friable sandstone and $0.2 \%$ mud rock. It also consists of pebble imbrications and conglomeratic horizons. Petrographic studies revealed quartz as the dominant mineral $(97 \%)$ which places the sandstone as quartz arenite. Other minerals include feldspar, limonite, zircon, opaque and minor clay matrix consisting 3\%. Geochemical results shows high concentration of Silica $\left(\mathrm{SiO}_{2}\right)$ and Aluminum $\left(\mathrm{Al}_{2} \mathrm{O}_{3}\right)$ in the sandstone which makes it mineralogical matured. Heavy minerals include Hematite $\left(\mathrm{Fe}_{2} \mathrm{O}_{3}\right)$ and Zircon $(\mathrm{Zr})$ while rare earth elements include $\mathrm{La}, \mathrm{Ce}, \mathrm{Nd}$, $\mathrm{Gd}$ and $\mathrm{Tb}$. Trace elements are $\mathrm{Cu}, \mathrm{Pb}$, $\mathrm{Zn}, \mathrm{Ag}, \mathrm{Sr}, \mathrm{V}$ and $\mathrm{Nb}$ which has pronounced enrichment in clay than the sandstones. The color variation of white, yellow and pink are indicative of fully aerated environment and has no effect on the geochemistry of the sandstones.
\end{abstract}

Keywords: Nekede, Azara Egbelu, Benin, Sandstone, Mud Rock, Arenite, Aerated

\section{Introduction}

The study area is situated within the geographical coordinates; Northing's $5^{0} 24^{\mathrm{I}}$ and $5^{0} 30^{\mathrm{I}}$ and Easting's $7^{0} 00^{\mathrm{I}}$ and $7^{0} 09^{\mathrm{I}}$ (Figure 1). It lies entirely in Imo State within the Benin Formation of the Niger Delta Basin, southeastern Nigeria. It is the surface exposure of the litho-stratigraphic units of the basin. It is bounded to the east by the Cameroon Basement Complex, the Oban massif and the Abakaliki fold belt. The Anambra Basin bounds it in the north while the Dahomey Basin and the Nigerian western Basement Complex bound it to the west respectively. The study area is within the humid tropics affected mainly by the southwest rain bearing winds and by the northeast trade (harmattan) winds which are dry and dust-laden. Thus the area experiences about eight months of rainfall (April to November) and four dry months (December - March).

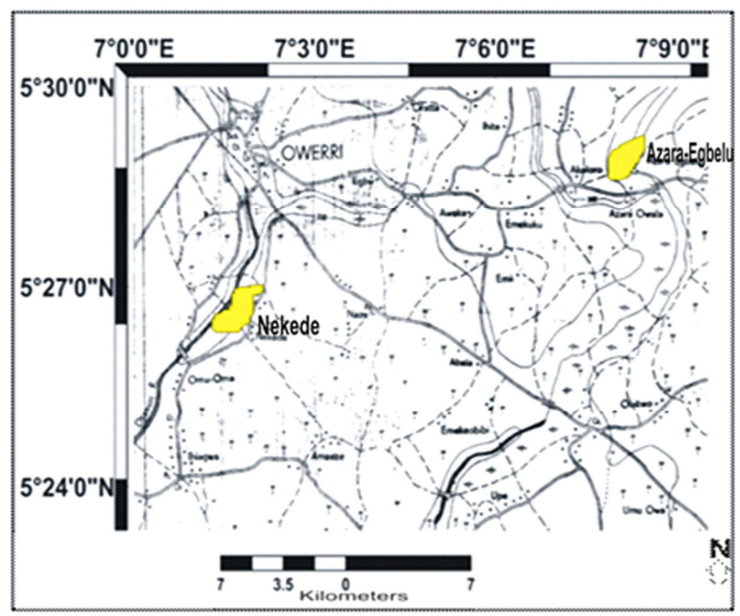

Figure 1. Location map of the study area. 


\section{Previous Work}

Previous workers such as [1], [2], [3], [4], [5], [6], [7], [8], [9], [10] and [11] reported that the Benin Formation consists of carbonaceous, massive and over $90 \%$ thick and very friable sand units which are mostly medium - coarse grained and locally with pods of fine grained sands with pebbly imbrications and conglomeratic horizons deposited during the Paleocene - Miocene. They also submitted that the sands are poorly sorted, sub-angular to well-rounded, and contain clay beds and lenses. They also reported that the Petrographic analysis of the rock shows that quartz makes up about $95 \%$ $99 \%$ of all the grains, $1 \%-2.5 \%$ of mica, $0.5 \%-1.0 \%$ feldspar and $2 \%-3 \%$ dark minerals. They concluded that chemical analysis revealed the presence of $\mathrm{TiO}_{2}, \mathrm{Al}_{2} \mathrm{O}_{3}$, $\mathrm{Fe}_{2} \mathrm{O}_{3}$, etc. with REE which include $\mathrm{Eu}, \mathrm{Gd}, \mathrm{Nd}$ etc.

\section{Geologic Setting}

The arcuate destructive and wave dominated type Niger Delta Basin is believed to be one the world largest Delta [12]. It is situated at the northeastern margin of the Gulf of Guinea on the west coast of Africa. The Okitipupa ridge separates the Niger Delta in the West from the Dahomey Basin. To the North, the Niger Delta is linked to the Benue Trough by the Cretaceous Anambra Basin. The Abakaliki uplift, the Cameroon Basement Complex and the Oban Massif bounds it to the northeast and east respectively and fed by the drainage systems of the Niger, Benue and Cross Rivers. The Niger Delta is considered structurally selfcontrolled since the structural features of the underlying Basement Complex do not seem to have directly influenced its tectonic development.

\section{Materials and Methods}

The spot sampling method was used in the field for collecting twenty five samples of sandstone, clay and conglomerates. The samples were collected from exposures in a sand quarry at Nekede and Azara Egbelu areas respectively (Figures 2 and 3). Ten representative samples were subjected to Petrographic analysis. XP 3000C microscope with $\times 20$ magnification was used to study slides at the headquarters of Nigerian Geological Survey Agency Abuja, Nigeria. Geochemical analysis was carried out by Acme Labs, Canada using LF 700 and MA 250 methods. Petrograph Version 1.0.5 software developed by Pirelli (2005) was used to plot the REE values.

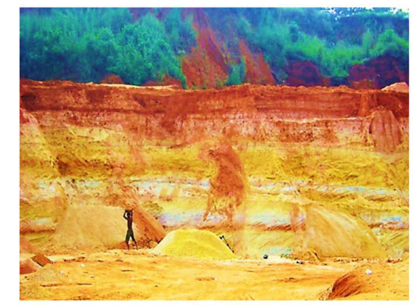

Figure 2. A typical coastal plain sands at Nekede.

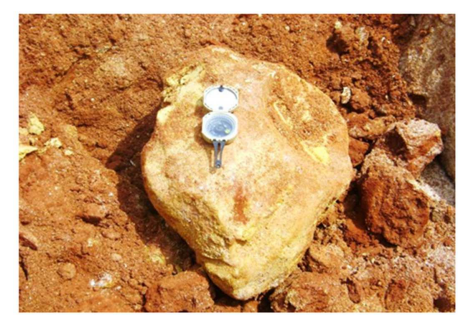

Figure 3. Boulder of clay in sandstone unit at Azara-Egbelu.

\section{Results}

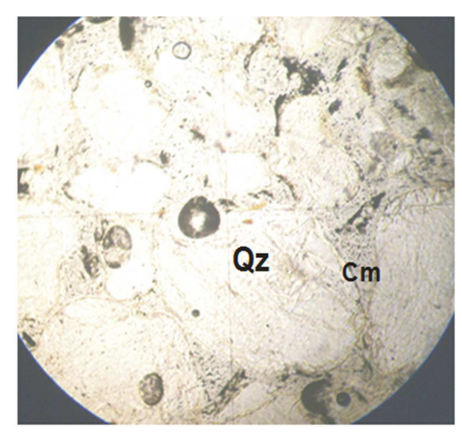

Figure 4. Medium grained sandstone (B) in plain polar.

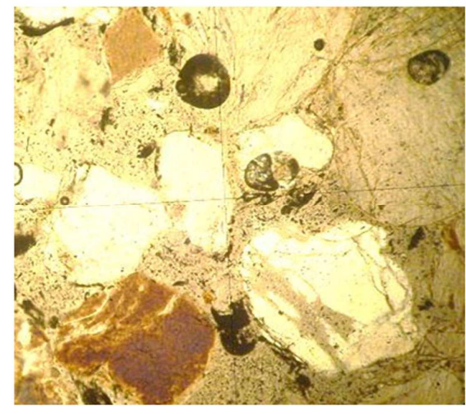

Figure 5. Medium grained sandstone (B) in cross polar.

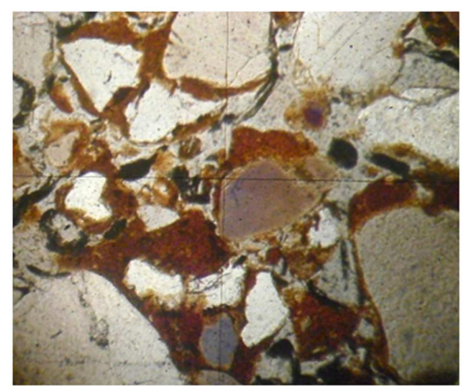

Figure 6. Ferroginized sandstone (Contact) in cross polar.

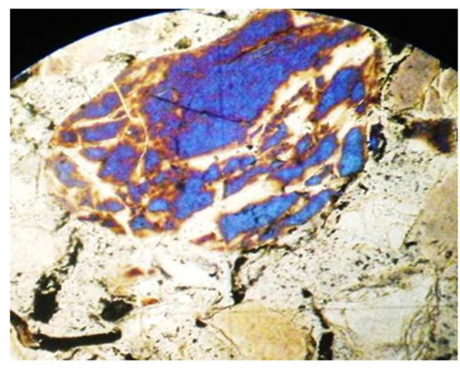

Figure 7. Medium grained sandstone (A) in cross polar. 
Table 1. Chemical compositions (oxide) of representative samples.

\begin{tabular}{lllllllllllllll}
\hline Samples & $\mathbf{S i O}_{2}$ & $\mathbf{A l}_{2} \mathbf{O}_{3}$ & $\mathbf{F e}_{2} \mathbf{O}_{3}$ & $\mathbf{C a O}$ & $\mathbf{M g O}$ & $\mathbf{N a O}_{2}$ & $\mathbf{K}_{2} \mathbf{O}$ & $\mathbf{M n O}$ & $\mathbf{T i O}_{2}$ & $\mathbf{P}_{2} \mathbf{O}_{3}$ & $\mathbf{C r}_{2} \mathbf{O}_{3}$ & $\mathbf{L O I}$ & $\mathbf{\%}$ \\
\hline Clay & 45.52 & 54.00 & 3.38 & 0.02 & 0.13 & $<0.01$ & 0.58 & $<0.01$ & 2.07 & 0.20 & 0.02 & 13.67 & 99.70 \\
Med. Sand (A) & 78.88 & 11.86 & 3.19 & 0.05 & 0.05 & $<0.01$ & 0.06 & 0.01 & 0.74 & 0.05 & $<0.01$ & 5.53 & 100.42 \\
Med. Sand (B) & 91.75 & 4.70 & 0.91 & 0.02 & 0.01 & $<0.01$ & 0.03 & $<0.01$ & 0.16 & 0.03 & $<0.01$ & 2.04 & 99.62 \\
Med. Sand (Contact) & 90.96 & 5.72 & 0.69 & 0.02 & $<0.01$ & $<0.01$ & 0.04 & $<0.01$ & 0.17 & 0.03 & $<0.01$ & 2.47 & 100.07 \\
Conglomerate & 100.15 & 0.36 & 0.28 & 0.02 & 0.01 & $<0.01$ & $<0.01$ & $<0.01$ & $<0.01$ & $<0.01$ & $<0.01$ & 0.16 & 101.11 \\
Fine sand & 92.84 & 4.69 & 0.24 & 0.02 & $<0.01$ & $<0.01$ & 0.04 & $<0.01$ & 0.15 & 0.03 & $<0.01$ & 1.99 & 99.98 \\
\hline
\end{tabular}

Table 2. Rare Earth Elements of representative samples.

\begin{tabular}{llllllll}
\hline Samples & La & Ce & Nd & Sm & Eu & Gd & Tb \\
\hline Clay & 94.3 & 232.37 & 132.2 & 25.7 & 6.2 & 18.6 & 2.5 \\
Med. Sand (A) & 40.1 & 95.97 & 29.7 & 4.8 & 0.8 & 2.2 & 0.4 \\
Med. Sand (B) & 26.9 & 58.29 & 21.6 & 4.3 & 0.8 & 2.9 & 0.4 \\
Med. Sand (Contact) & 30.3 & 62.07 & 23.7 & 4.8 & 0.9 & 2.4 & 0.3 \\
Conglomerate & 7.4 & 13.92 & 4.7 & 1.0 & 0.2 & 0.5 & $<0.1$ \\
Fine sand & 32.6 & 66.60 & 25.5 & 4.9 & 0.9 & 2.8 & 0.4 \\
\hline
\end{tabular}

Table 3. Trace elements of representative samples.

\begin{tabular}{lllllllllllllllll}
\hline Samples & $\mathbf{M o}$ & $\mathbf{C u}$ & $\mathbf{P b}$ & $\mathbf{Z n}$ & $\mathbf{A g}$ & $\mathbf{N i}$ & $\mathbf{C o}$ & $\mathbf{M n}$ & $\mathbf{A s}$ & $\mathbf{U}$ & $\mathbf{T h}$ & $\mathbf{S r}$ & $\mathbf{V}$ & $\mathbf{L i}$ & $\mathbf{N b}$ & $\mathbf{Z r}$ \\
\hline Clay & 1.42 & 13.18 & 74.92 & 38.2 & 407 & 23.9 & 3.7 & 80 & 4.7 & 21.3 & 160 & 160 & 163 & 7.0 & 58.48 & 224.8 \\
Med. Sand (A) & 1.64 & 9.82 & 27.36 & 20.9 & 45 & 22.2 & 2.8 & 96 & 3.4 & 2.0 & 17.2 & 2.4 & 59 & 64 & 26.03 & 146.6 \\
Med. Sand (B) & 0.47 & 3.96 & 21.37 & 6.8 & 40 & 10.4 & 0.9 & 20 & 1.8 & 0.7 & 4.9 & 24 & 26 & 2.8 & 5.37 & 38.9 \\
Med. Sand (Contact) & 0.73 & 3.82 & 21.58 & 7.9 & $<20$ & 10.0 & 0.8 & 16 & 1.1 & 0.9 & 6.8 & 23 & 34 & 3.5 & 6.21 & 50.8 \\
Conglomerate & 0.17 & 2.22 & 5.08 & 1.3 & $<20$ & 2.7 & 0.4 & 14 & 1.1 & $<0.1$ & 0.5 & 8 & 3 & 1.3 & 0.82 & 3.3 \\
Fine sand & 0.45 & 2.94 & 21.51 & 5.2 & 22 & 7.8 & 0.8 & 17 & 1.1 & 0.7 & 6.3 & 24 & 19 & 2.8 & 5.21 & 46.1 \\
\hline
\end{tabular}

\section{Discussion of Results}

\subsection{Granulometric}

Granulometric analysis shows that medium grained sandstone $(38 \%)$ dominates the area. It shows mainly unimodal through bimodal, trimodal and polymodal distribution of sand, poorly sorted and texturally matured Sandstone. Mesokurtic to very leptokurtic suggest that the sediments were derived from more than one source. Scatter plots of skewness versus standard deviation and simple skewness measure versus simple sorting measure plotted showed that over $95 \%$ of the samples are beach sands suggesting a shallow marine environment of deposition.

\subsection{Petrography}

Photomicrographic studies revealed that the sandstone is poorly sorted, oval in shape and randomly dispersed in a clay and iron matrix. It also reveals the presences of quartz, feldspar, iron, zircon and some opaque minerals. Quartz minerals appear colorless - cloudy, low birefringence and low relief respectively (Figure 4). Under cross polar, quartz crystals have low interference color and goes into undulose/wavy extinction displaying colorless to creamy $1^{\text {st }}$ order interference colors (Figure 5). On the rim of the quartz crystal of the ferroginized sandstone (Figure 6) is a high relief mineral crystal. It is reddish in color with low interference color and does not go into extinction nor is it pleochroic. This mineral is an indication of iron probably a mixture of hematite and goethite. Associated with the quartz crystals in Figure 7 is a crystal of zircon mineral that has a high relief and high interference colors set in the medium grained sandstone groundmass. It occurs prismatic, short, anhedral to subhedral in shape. Some of the crystals have either rhombohedral or pseudo-hexagonal outlines. The crystals show partings and/or fractures close to the edges. The mineral has moderate birefringence of $2^{\text {rd }}$ order blue interference colors (Figure 7). The modal compositions of the representative samples are presented in table 4 . The mineralogical maturity of the sandstone is as a result of low content of feldspar and rock fragments and the preponderance of quartz in the sandstone could be due to either profound chemical weathering of granitic rocks of the Cameroon Highlands in a climatic environment very similar to present day humid conditions, long transportation history over a relatively low relief and/or from the recycling of the older sandstones [13]. The oval shape indicates textural maturity.

Based on the mineral composition and texture, the relative abundance of quartz over all other minerals, the sandstone facies can be classified as quartz arenite (Figure 8) [14]. Feldspar and rock fragments are generally more susceptible to chemical than mechanical weathering [15]. Hence, they are destroyed much faster in humid and hot climate even over short transport and high relief. This is evident in the sediments. It is therefore evident that the Cameroon Basement Complex, the Oban Massif and or the Abakaliki Fold Belt to the east are the most probable sources of igneous, metamorphic and sedimentary rocks that generated the coastal plain sands. 
Table 4. Modal compositions of representative samples.

\begin{tabular}{|c|c|c|c|c|c|c|}
\hline Mineral / Sample & Quartz & Feldspar & Zircon & Opaque & Hematite & Rock Fragment \\
\hline Fine grained sand & 91 & 2 & 5 & 1 & - & 1 \\
\hline Medium grained sand (A) & 95 & 2 & - & 1 & - & 2 \\
\hline Medium grained sand (B) & 90 & 2 & - & 1 & 5 & 2 \\
\hline Medium grained sand (contact) & 94 & 1 & - & 1 & 1 & 3 \\
\hline Conglomerate & 98 & - & - & 1 & 1 & - \\
\hline
\end{tabular}

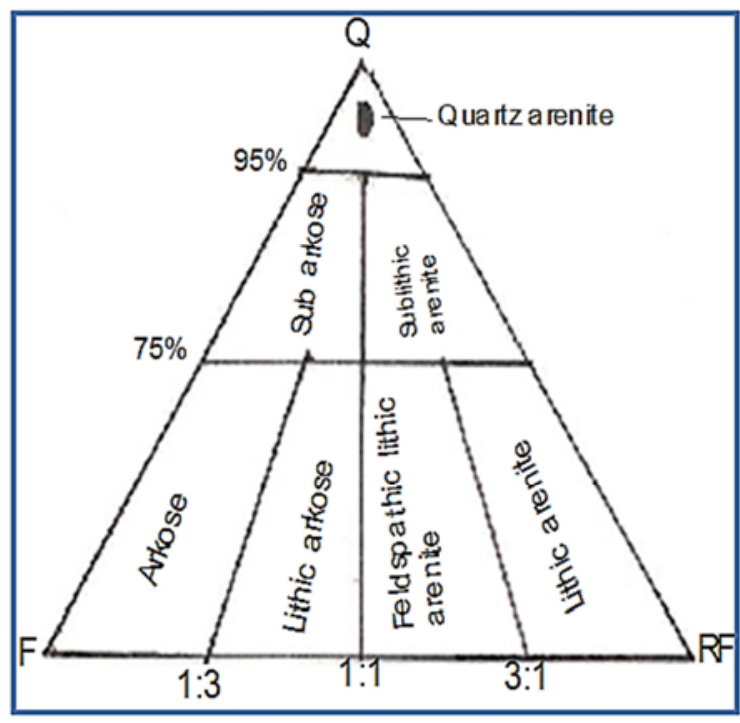

Figure 8. F/R Ratio.

\subsection{Geochemistry}

The analytical results of representative samples are presented in tables 1,2 and 3 respectively. Sandstone and conglomerate show great enrichment in silica $\left(\mathrm{SiO}_{2}\right)$ ranging from $91.75-100.15 \%$ while it is significantly low in clay constituting $45.52 \%$ (Table 1 and Figure 9). Aluminum $\left(\mathrm{Al}_{2} \mathrm{O}_{3}\right)$ values are lower in all the sandstones $(0.16-5.57 \%)$ while it is significantly higher in clay $(34.00 \%)$ and the medium grained sandstone (A) $(11.86 \%)$. The value of iron oxide $\left(\mathrm{Fe}_{2} \mathrm{O}_{3}\right)$ is higher in the clay $(3.83 \%)$ and the medium grained sandstone (A) (3.19\%) while it is less than 1 in all the other sandstones samples. Titanium $\left(\mathrm{TiO}_{2}\right)$ is high in the clay $(2.07 \%)$ and less than 1 in all the other samples. Again, the high silica content in the sandstone samples indicate textural and mineralogical maturity of the sandstone and the high content of aluminum in clay suggest weathering of micas and feldspars and subsequent reaction with water.

The high content of iron oxide in medium grained sandstone (A) is as a result of weathering of the top soil. The normalized chondriate spidergram of Sun and Mc Donough shows an enriched light rare earth element (LREE) and depletion in the intermediate rare earth element (MREE) and low high rare earth elements (HREE) respectively (Figure 10). Granitic rocks rich in $\mathrm{Rb}$ and $\mathrm{Cs}$ are believed to be highly evolved and likely to host rare metal. The trace element revealed high concentration of copper $(\mathrm{Cu})$, Manganese $(\mathrm{Mn})$, lead $(\mathrm{Pb})$ and niobium $(\mathrm{Nb})$ in clay and medium grained sandstone (A) while it is low in all other samples. This is due to weathering. A positive skewness shows the rocks have a granitic character. LOI values are higher in the clay (13.67) and the medium grained sandstone (A) (5.53) while it is less than 2 in all other samples. The high silica oxide $\left(\mathrm{SiO}_{2}\right)$ values in the sandstones, high aluminum and iron in the clay, the presences of high value of zircon agree with the Petrographic studies.

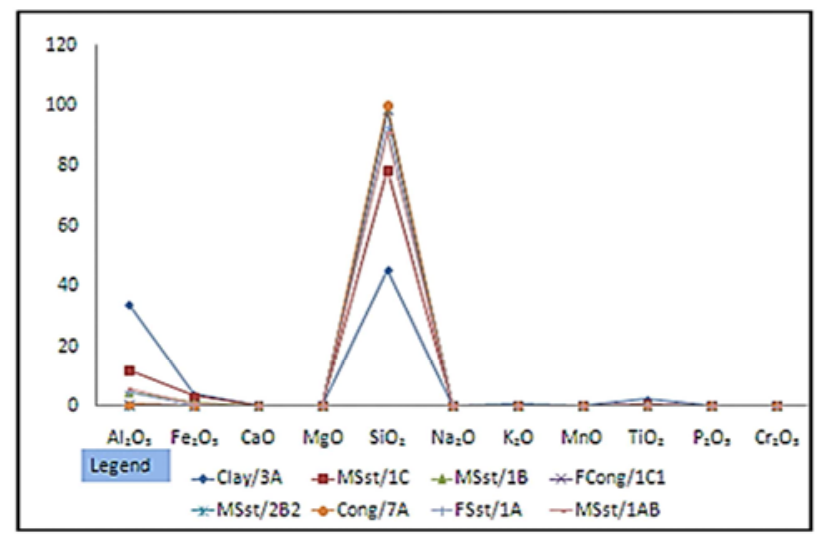

Figure 9. Chemical compositions of representative samples.

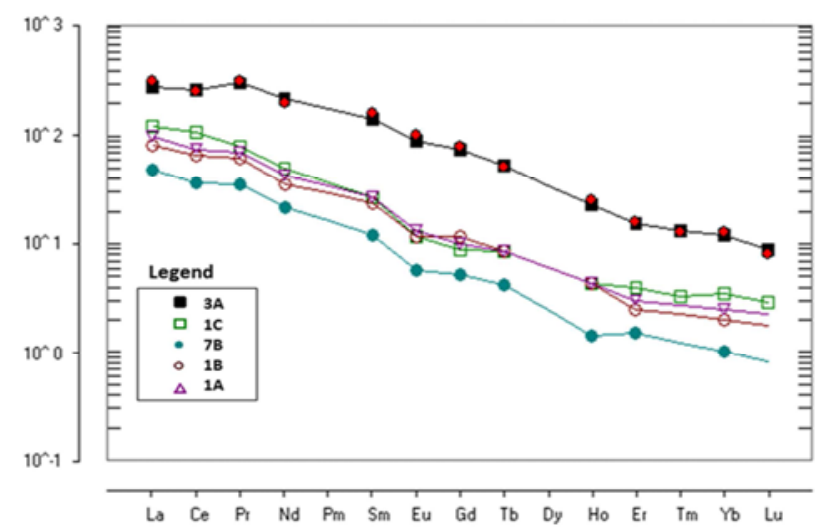

Figure 10. REE Chondriate diagram of representative samples (After Sun and McDonald (1989) in PetroGraph software version 1.0.5 (2005)). (Note: 3A-Clay, 1C-Medium grained sand, 1B-Medium grained sand (contact), 1AFine grained sand and $7 B$-Conglomerate).

\section{Conclusions}

The present study has further confirmed that the coastal plain sands facies of the Niger Delta Basin constitutes $99.8 \%$ sandstones and $0.2 \%$ clay. The sandstons are mineralogically and texturally matured, fine - medium grained, poorly sorted, rnesokurtic - leptokurtic and symmetric distribution. It is mainly bimodal - trimodal through polymodal distribution. 
Petrographic analysis indicated the presences of heavy minerals (zircon and Hematite). The grain shapes of the minerals are mostly anhedral - subhedral. Zircon shows fractures while the rock fragments are mostly spindle. Geochemistry reveals high concentration of silica in the sandstones and conglomerates with lower values in the clay. Clay shows high concentration of aluminium compared with other sandstone samples. The chondriate spidergram revealed high enrichment in LREE which is depleted in MREE and HREE respectively. Clay and medium grained sandstone (A) revealed high concentration of lead and niobium compared with other samples. The source of the coastal plain sands is derived from the Cameroon Basement Complex, the Oban Massif, and/or the Abakaliki Fold Belt.

\section{Acknowledgements}

Our profound gratitude goes Nigerian Geological Survey Agency (NGSA) and the Director General Mr. A. N Nweagbu for providing the required resources for the research. We also appreciate the assistance given to us by the former Director, Department of Regional Geology, Mr. G. P. Abhulimen and the Assistant Director in-charge of NGSA Owerri Office Mr. Osuremi. Finally, to the driver, Musa Jodi and the field attendants Mr. Maxwell and Joseph, we say thank you all.

\section{References}

[1] L. C. Amajor and O. D. Ngerebara Significance of compositional and textural properties of sands form western Andoni beach and flanking rivers (Andoni and Imo) eastern Niger delta, Nigeria. Journal of mining and geology, vol 26, No 2, 1990.

[2] Shell D'Arcy Petroleum Development Company of Nigeria Limited (1938).

[3] R. A. Reyment. Aspects of Geology of Nigeria, Ibadan University Press, Nigeria. 1965 145p.

[4] K. C. Short and A. J. Stauble. Outline of the Geology of the Niger Delta: Bulletin of the American Association of Petroleum Geologist, vol 51pp 764-779.1967.
[5] A. C. Onyeagocha Petrography and Depositional Environment of the Benin Formation, Nigerian Journ. Mill. Geo!. 17, 14715 I. 1980.

[6] S. F. Ananaba N. N. Onu and C. J. Iwuagwu. Geophysical study of the gravel Deposit in Ihiagwa, Owerri. Nigeria Jour. Min. Geol. 29, (4), 93-100. (1993).

[7] K. M. Ibe (Sr), A. O. Sowa and O. C. Osondu. Environmental Contamination and Other Anthropogene Impacts on Otamiri and Nwaore Rivers, Owerri, Nigeria. journal of mining and geology vol. 28 no. i 1992.

[8] O. C. Freeborn. Geoelectric Investigations for Groundwater in Aniocha South Local Government area of Delta State. Global Journal of Geological Sciences, Vol 4, No.2 2006.

[9] C. S. Nwajide. Petrology and Paleogeography of the Makurdi Formation, Benue Trough. $\mathrm{PhD}$ Thesis submitted to the Department of Geology in the Faculty of Physical Sciences, University of Nigeria, Nsukka. P 1982 Unpublished.

[10] C. S. Nwajide. Training course on sedimentological techniques organized by the Nigerian Geological Survey Agency, Abuja. Unpublished 2008.

[11] C. S Nwajide. J, F. Ogala, I. M. Akaegbobi and E. O. Adaikpoh. Sedimentologic Characteristics of the Maastrichtian Fluvio-Marine Sandstones Facies of the Anambra Basin. African Scientist, Vol 6, Vol 312005.

[12] A. A Edward. Chemostratigraphy study of Radioactive Reservoir in Part of Niger Delta, Nigeria. MSc project submitted to the Department of Geology, University of Ibadan, Nigeria. 2006.

[13] J, F. Ogala, I. M. Akaegbobi and E. O. Adaikpoh. Sedimentologic Characteristics of the Maastrichtian FluvioMarine Sandstones Facies of the Anambra Basin. African Scientist, Vol 6, Vol 312005.

[14] R. L. Folk, Geophysical study of the gravel Deposit in Ihiagwa, Owerri. Nigeria Jour. Min. Geol. 29, (4), 93100.1974 .

[15] G. H. Mack and L. J. Suttner.. Paleoclimatic interpretation from a petrogcomparism of Holocene sands and the fountain of (Pennyslyvanian) the Colorado Front Range. Journ. Sed. Petrol., 47, p. 89-100. 1977. 